\title{
PODOBY A PREMENY SPOLOČENSKEJ PRÓZY PRE DETI
}

\author{
(ilustrované na tvorbe Jána Kopčoka a Juraja Tušiaka)
}

V príspevku sa hovorí o spoločenskej próze prvých dvoch významných autorov v slovenskej vojvodinskej literatúre pre deti po roku 1945 - Jána Kopčoka a Juraja Tušiaka. Ich podobné naratívne modely príbehovej prózy v 50. rokoch patria do tzv. spomienkovej prózy. Kým u Kopčoka dominuje schematický príbeh o vel'kých detských činoch počas vojny alebo uniformovaný príbeh o nemotivovanej zmene detského hrdinu, u Tušiaka evidujeme odklon od tradičného realistického rozprávania smerom k modernej próze. Najprv do príbehov z vlastného detstva vnáša prvky dobrodružnosti a humoru, a v knihách z prvej polovice 70. rokov i moderné výrazové postupy, predovšetkým priameho rozprávača, vnútorný monológ, polopriamu reč, hovorový jazyk a detský slang. Tušiakov autentický obraz detstva s hrdinom všedného dňa sa výrazne podiel'al na vývine príbehovej prózy pre deti v d'alších desat'ročiach.

Klúčové slová: slovenská vojvodinská literatúra pre deti, spoločenská próza pre deti, príbehová próza, hrdina všedného dňa, Ján Kopčok, Juraj Tušiak

The paper explores the social prose of the first two significant authors for children after 1945 in the literature of Slovaks in Vojvodina: Ján Kopčok and Juraj Tušiak. Their narrative models of storytelling in 1950s are known as the prose of memories. While Kopčok uses predominantly schematic narration about big events during the war, where the main actors are children, or a uniform story about an unmotivated transformation of a child hero, Tušiak deviates from traditional realistic storytelling and reaches modern prose. At first, Tušiak included the elements of adventure and humor to stories of his own childhood and in his work from the early 1970s he also included modern types of expression such as a direct narrator, internal monologue, indirect and direct speech, children's slang. Tušiak presented an authentic image of childhood with a hero from everyday life and thus he greatly contributed to the development of children's storytelling over the coming decades.

Key words: children's literature of Slovaks in Vojvodina, social prose for children, storytelling, everyday hero, Ján Kopčok, Juraj Tušiak.

V kontexte slovenskej vojvodinskej literatúry pre deti a mládež ako v diachrónnom tak i v synchrónnom priereze dominuje spoločenská próza pre deti. Permanentná prítomnost' či regenerácia tohto žánrovo-tematického podsystému detskej literatúry, ktorý literárna teória zvykne nazývat’aj príbehová próza zo života detí je zakódovaná $\mathrm{v}$ jej špecifikách, kde v prvom rade patrí vysoká referenčná nadväznost' na realitu. Slovenská teoretička a kritička Zuzana Stanislavová dlhodobo sa zaoberajúca práve týmto žánrovým okruhom hovorí, že "témou je život detí a mládeže v l’udskom spoločenstve so všetkými súvislost’ami, ktoré $\mathrm{k}$ tomu patria, uchopený obyčajne prostredníctvom kratšieho výseku zo životných osudov, zážitkov a príhod zvolenej postavy" (1995: 12). Príbehová próza zo života detí sa intenzívnejšie začína pestovat' po roku 1945, najmä na stranách detského časopisu Naši pionieri, kde uverejňovali aj prví významní autori Ján Kopčok a Juraj Tušiak. 
Jána Kopčoka (1929 - 1993) môžeme pokladat' za typického predstavitel’a príbehovej prózy v prvom desat'ročí po vojne. V prvej knihe pre deti u nás Deti z našej ulice (1959), zostavenej z časopisecky uverejnených poviedok, autor vychádzal z vlastných zážitkov z rokov detstva a dospievania počas vojny (v prózach Jankov odvážny skutok, Príhoda v noci, Útek, Prechod cez rieku; v poslednej hovorí o udalosti, ktorej bol sám svedkom počas bojov pri Dráve) alebo z učitel'skej praxe. Detské postavy sú často nositelia hrdinských skutkov, ktoré prevyšujú ich vek a v ich činoch sa črtá istá dobová tendenčnost' (v próze Zachránený nejde len o pomoc človeku v núdzi; deti pomáhajú ranenému idealizovanému partizánovi). O detských príhodách a zážitkoch Kopčok vypovedá z pozícií autorského subjektu, diet’a je často objektom poúčania (Požiar, Závistlivá Kata, Lekár); napríklad v sentimentálne ladenej próze Lekár sa didaktickým objektom stáva lenivý syn chorej matky. Lekár nielenže ho napomína, ale mu ukladá aj mravnú zodpovednost' za matkin stav: „Ak zomrie, ty ju budeš mat' na svedomí..." (Kopčok 1959: 85) Uniformovaný príbeh hovorí o nemotivovanej zmene hrdinu - neposlušné, lenivé diet’a, spravidla zo sociálne nezaopatrenej rodiny, sa mení na dobrého a uvedomelého člena spoločnosti v zmysle svojich pionierskych a žiackych povinností. Aj kompozícia poviedok je ustálená; v úvode sa nachádza opis (prostredia, prírody, postavy) alebo stručná expozícia do deja, nasleduje vlastný dej poviedky s konfliktom, ktorý sa nakoniec nemotivovane vyrieši. Súvisí s tým i didaktizmus: previnilec spoznáva čo je dobré a čo zlé a nasleduje jeho obrátenie (Nezbedný Jurko, Marka a iné). Schematizmus Kopčokovho prozaického modelu sa prejavuje aj v d’alších typických znakoch jeho próz: idealizácia postáv (Príhoda $v$ noci), antagonizmus (poctivého) chudobného a (pyšného) bohatého diet'at’a (Prvý sneh, Naša záhrada), mravoučné tendencie (Strakatá vrana) s explicitným odkazom, že zlo býva potrestané (Samko vrabčiar).

Kritika (pozri Hodoličová 2005: 132-133) už poukázala na Kopčokove umelecky vyspelejšie poviedky Hostina (1981) a Johann (1985), ktoré vyšli pod názvom Chlapci zo salaša (1986). Konanie detských postáv je psychologicky motivovanejšie a v súlade $\mathrm{s}$ ich ontogenézou (napr. nevedia presne, kto sú partizáni a iba tušia, že spolupráca so žandármi je zlá). K ich živosti a plastickosti prispieva i humorné modelovanie príbehu (pomsta starému geregárovi Sabadošovi za urážku a za spoluprácu so žandármi, na geregách pre Nemcov povypisuje partizánske heslá). V narácii je menej popisnosti a tendenčnosti. Už v 70. rokoch, zrejme pod vplyvom nových moderných naratívnych tendencií v próze pre deti, sa aj Kopčokova poetika čiastočne mení; v prózach, ktoré vtedy uverejňoval časopisecky nachádzame príbehy s jasným poučujúcim zámerom (Červené gladioly), autobiografickým podkladom (Slzy), ale i dynamické príbehy s detským rozprávačom s motívom detskej hry (Prečo?) alebo slovnej hračky (Kto čo robí, ked’ vstáva).

Pre vývin príbehovej prózy s detským hrdinom má dôležité miesto tvorba Juraja Tušiaka (1935 - 1986). V debute O bielom jeleňovi (1961) vychádza z návratov do vlastného chudobného detstva. Napriek naznačeným sociálnym (nádenníctvo, tuberkulóza) a spoločenským elementom (obdobie vojny), ktoré prislúchajú realistickému rozprávaniu Tušiakova kniha anticipovala dôležitú zmenu v príbehovej próze s chlapčenským hrdinom. Celý rad dobrodružno-romantických prvkov (tajomný poklad, dobrodružná cesta, zázračnost' povesti o bielom jeleňovi či legendy o zlatej koze) v dobrodružne a humorne ladených chlapčenských príbehoch $O$ zlatej koze a 
„Afrikáni“" signalizovali premenu zautomatizovaného tradičného príbehu pre deti, ktorý reprezentovala Kopčokova tvorba.

Už d’alšie dve Tušiakove knihy Maximilián v meste (1971) a Štvrtácka jar (1975) prinášajú celý rad inovačných podnetov do zaužívaného naratívneho modelu príbehovej prózy pre deti. $\mathrm{V}$ tematickej oblasti ide o zmenu priestoru odohrávania sa príbehov z vidieckeho do mestského prostredia ( $\mathrm{v}$ titulnej novele Maximilián v meste a v druhej knihe), čo kritika zdôrazňovala ako zásadnú zmenu (Hodoličová, 2005), ale ešte výraznejšia je zmena rozprávačských a kompozičných postupov. Do poviedok sa dostávajú živé detské postavy a ich autentické detstvo. Hrdina „v̌̌edného dňa“ nie je idealizovaný, je šibal a výmyselník, zaradený do širšieho spoločenského prostredia rodiny alebo vrstovníkov. Tušiak tu mení autorskú stratégiu, ide o budovanie dôvernejšieho a otvorenejšieho vzt'ahu s recipientom. Kl'účové je rozprávanie v prvej osobe, implikuje zmenu jazyka a štýlu diel. Využíva sa detská hovorová reč a detský slang, čo Mária Myjavcová (1972) dala do súvisu s modernou slovenskou prózou. ${ }^{1}$ Prózy v knihe Maximilián v meste (okrem prózy Listy s dievčenskou hrdinkou) môžeme zaradit' do okruhu chlapčenskej prózy (napr. zakladanie detských skupín s vlastnými pravidlami a tajnými úkonmi, sútaženie v zdatnosti). Konflikt pramení zo vzt’ahových relácií medzi protagonistami, dokazujú svoju fyzickú i psychickú prevahu (ale nie v zmysle zveličených činov Kopčokových detských postáv), čo je často prepojené s psychologicky motivovanou vnútornou zmenou. Ako príklad môžeme uviest' prózu Obrat Samka Zlocha (negatívny hrdina sa v čase dospievania stane citlivým a empatickým), ale i Druhý breh (členovia detskej družiny si svoju pozíciu v detskej partii vydobýjajú hrdinským a nebezpečným činom - preplávajú Dunaj).

V knihe Štvrtácka jar Tušiak v ret’azovito pospájaných prózach tematizuje život jedenástročného štvrtáka Milana od jari do leta $\mathrm{v}$ školskom a rodinnom prostredí. Všedný každodenný život sa podáva dobrodružne. Milan je prototypom hrdinu všedného dňa, je neposedný, nie najlepší žiak, vymýšla si, dostáva sa do konfliktov. Relatívne harmonické prvé kapitoly sa komplikujú v strede knihy v epizóde Zase začinam mat' smolu, nasledujú časti Ked' ja neviem vymýšlat' a Chodia $k$ nám duchovia, kde sa Milan bojí priznat' a vysvetlit' otcovi ako rozbil jeho náramkové hodinky. Dráma sa však neodohráva iba v kruhu rodiny, ale i v Milanovom vnútri. Ich rozprávanie a prúd vedomia umožňujú hlbší psychologický prienik do jeho vnútorného sveta: „A čo by len bolo, keby som sa priznal? Ocko by ma určite zbil, lebo by mi neveril, že som to nechcel urobit', že som sa len hral, lebo on sa hrat' nevie, už zabudol. On hodinky má, a preto nevie, ako je to nemat' hodiniek.“ (Tušiak 1975: 93) Radikálna zmena nastala, podl'a našej mienky, práve $\mathrm{v}$ kategórii rozprávača. Uvádzanie priameho rozprávača umožňuje uplatnenie i iných kompozičných postupov ako sú časté digresie, vnútorný monológ, využitie priamej a polopriamej reči a pod. Mienime, že klúčové sa stáva narábanie s časovými rovinami. Rozprávač a postava Milan napríklad v epizóde Ked' ja neviem vymýšlat je v škole a má písat' sloh na tému zaujímavej príhody. Prácu nenapíše, ale vo vlastnom rozprávaní pospomína celý rad

${ }^{1}$ Tušiak zrejme poznal pôvodnú i prekladovú produkciu generácie detského aspektu zo 60. rokov 20. storočia. Dôkazom toho je zavádzajúci názov prózy „,Emil a detektívi“; odkazuje na detektívny charakter prózy, ale ide vlastne iba o prítomnost' rovnomennej knihy nemeckého autora Ericha Kästnera v príbehu, ktorá svojim obsahom odpúta pozornost' unudeného učitel'a od vlastnej karikatúry.

Славистика XXII/2 (2018) 
zaujímavých a dynamických príhod. Často ide o asociatívne nadväzovanie vlastné detskému mysleniu a detskému rozprávačovi, napr. pri zmienke ako mama na výlete háčkuje odbočí ku konfliktu kvôli prehorenej čipke od zabudnutej otcovej cigarety v popolníku. Detský zorný uhol umožňuje postrehnút komplexnost' vzt’ahov vo svojom okolí; napríklad v rodine, podané spontánnou hovorovou rečou: „Vie to i otecko: vie, že mama vie, že i on sám vie, že je trochu lenivý, a to ho trochu zlostí.“ (Tušiak 1975: 44), ale i lásky a rodinnej súdržnosti: „Len otecko žuje pomaly. Akoby nasilu. - Keby si vedela, kol'ko mi všetci traja znamenáte... - povie a uprene sa zadíva na mamu. Čaká odpoved'. Ale? - usmeje sa mama, položí ockovi ruku na plece a jemne ním potrasie. - Ved’ už jedz!““ (Tušiak 1974: 52) Dôležitú úlohu tu zohráva pohl’ad, dotyk či gesto: „,To mu je trest!' chcela povedat' Mila (tie dva dináre jej nevrátim!), ale sa zháčila a nepovedala, len nakríž zovrela dlane, že mi drží palce (vrátim jej!)“. (Tušiak 1975: 30) Vel'mi subtílne detský rozprávač dokázal znázornit' vzt’ah medzi ním a otcom: „Sám viem, že ho musím poslúchat', lebo je môj. Povie: Pod”! - a idem. Povie: Nejdi! - a nejdem. Povie: Mlč! - a mlčím. Povie: vrav - a vravím. Povie: Neklam! - a neklamem. Ja skutočne nikdy neklamem (ked' ide o niečo vážne). A ak potom niekto povie, že klamem, len sa zatnem a mlčím, lebo som neklamal.,, (Tušiak 1975: 67) alebo „pohladom zdola“: "Vediem si ocka za ruku. /---/,,- Ocko, to nič, že si mi ocko; dôležité je, že sme priatelia." (Tušiak 1975: 74) Detské videnie sveta evidujeme aj vo vtipných poznámkach (Števko divadlo hrat' nemôže, lebo javisko je malé, vlak pomaly priberal na rýchlosti, lebo nás bolo vel’a), v dvojplánovom významovom dianí, napr. ked' Milan donesie domov žiacku knižku sleduje matkine reakcie a zdá sa mu, že mama plače od štastia. V druhom významovom pláne je jasné, že zaslzí nad Milanovou trojkou z matematiky ako príčinou narušeného vzt’ahu medzi ním a otcom.

Na rozdiel od Kopčokovho realistického a schematického naratívneho modelu, Tušiak využitím moderných rozprávačských postupov (ich rozprávanie, vnútorný monológ, retrospektíva a i) podal autentický obraz detstva s hrdinom všedného dňa a výrazne sa podiel'al na vývine príbehovej prózy pre deti v d’alších desat'ročiach.

\section{Použitá literatúra}

Hodoličová, Jarmila. Prehl'ad dejín slovenskej vojvodinskej prózy pre deti. Beograd: Zavod za udžbenike i nastavna sredstva, 2014.

Stanislavová, Zuzana. Priestorom spoločenskej prózy pre deti a mládež. Interpretačné štúdie. Prešov: Pedagogická fakulta UPJŠ, 1995.

Myjavcová, Mária. „Detstvo plné zážitkov“. Nový život, 1972: 269-272.

\section{Pramene}

Kopčok, Ján. Deti z našej ulice. Petrovec: Kultúra, 1959.

Kopčok, Ján. Chlapci zo salaša. Nový Sad: Obzor, 1986.

Tušiak, Juraj. O bielom jeleňovi. Petrovec: Kultúra, 1961.

Tušiak, Juraj. Maximilián v meste. Nový Sad: Obzor, 1971.

Tušiak, Juraj. Štvrtácka jar. Nový Sad: Obzor, 1975. 
Зузана Чижикова

\section{МОДЕЛИ И ПРОМЕНЕ ПРОЗЕ ЗА ДЕЦУ СА САВРЕМЕНОМ ТЕМАТИКОМ (НА ПРИМЕРИМА ИЗ ДЕЛА ЈАНА КОПЧОКА И ЈУРАЈА ТУШИАКА)}

\section{Резиме}

Јан Копчок (1929-1993) и Јурај Тушиак (1935-1986) су први значајни аутори за децу у словачкој војвођанској књижевности после 1945. године који су писали прозу са савременом тематиком. У првим стваралачким фазама евидентирамо низ сличности у њиховој прози са тематиком повратка у детињство. Код Копчока у првој књизи Деиа из наме улице (1959) доминира схематизована проза о великим дечијим јунаштвима за време рата или устаљен наративни модел у коме се дечји јунак немотивисано мења у позитивног и узорног ученика и члана колектива. Код Тушиака се већ у првој књизи О белом јелену (1961) уочава превазилажење традиционалног реалистичког начина приповедања у правцу модерне прозе. Писац у прозу уводи авантуристичке и хумористичке елементе. Његове књиге из 70. година су у знаку модерних наративних поступака: уводи приповедача у првом лицу, унутрашњи монолог, дечји сленг и др. Његов јунак више није идеализован и беспризоран, његова оптика омогућава стварање аутентичне слике детињства са јунаком свакодневице. Управо је Тушиакова проза за децу са савременом тематиком имала снажан утицај на даљи развој овог жанра у словачкој војвођанској књижевности за децу и омладину.

Кључне речи: словачка војвођанска књижевност за децу, проза са савременом тематиком, наративна проза, јунак свакодневице, Јан Копчок, Јурај Тушиак. 